\title{
USE OF MIP OES AND F AAS/AES FOR DETERMINATION OF Ca, K, Na AND Mg IN BRAZILIAN CREAM CHEESE
}

Leila M. N. Diniz, Thaiane S. Carrasco, Aline L. Medina, Anderson S. Ribeiro and Adriane M. Nunes*

Centro de Ciências Químicas, Farmacêuticas e de Alimentos, Universidade Federal de Pelotas, CEP 96160-000, Capão do Leão RS, Brasil

Recebido em 25/10/2016; aceito em 09/03/2017; publicado na web em 15/05/2017

\begin{abstract}
In this work, two sample preparation procedures for subsequent determination of $\mathrm{Na}, \mathrm{K}, \mathrm{Ca}$ and $\mathrm{Mg}$ by techniques of atomic spectrometry in samples of Brazilian cream cheese were evaluated. The determinations were performed on two equipments, F AAS and MIP OES, which presented similar results, being evident the advantages of MIP OES since it is a multielementar technique with low operational cost and high efficiency. The first procedure was carried out by acidic decomposition $\left(\mathrm{HNO}_{3} / \mathrm{H}_{2} \mathrm{SO}_{4}\right)$ in a reflux system, and the second used the alkaline solubilization with tetramethylammonium hydroxide. The accuracy was verified by recovery tests and the results were between 80 and $104 \%$ for both procedures. A comparison with a reference procedure was also performed and no significant differences have been observed at the $95 \%$ confidence level. The evaluated elements were not in accordance with the values indicated on the labels of all products, showing the importance for monitoring these products. The methods of sample preparation proposed showed to be simple, inexpensive, providing accurate and precise results, and are a promising alternative to be used for the quality control of these routine test samples.
\end{abstract}

Keywords: Brazilian cream cheese; acid decomposition; alkaline solubilization; F AAS; MIP OES

\section{INTRODUCTION}

Recently there has been growing discussion about the need of reducing the sodium content in some dairy products, like milk drinks, mozzarella and Brazilian cream cheese (locality known for "requeijão"). The nutritional sodium requirement for humans is low (500 mg), about $1.2 \mathrm{~g}$ salt per day. However, the Family Budget Research (POF) of 2002-03 and 2008-09 showed that over 70\% of the population consumes $\mathrm{Na}$ in excess. The estimated average daily intake is $12 \mathrm{~g}$ salt/person, ${ }^{1}$ well above the recommendations defined by the World Health Organization, which establishes the maximum daily limit of $5 \mathrm{~g}$ of salt (which corresponds to $2 \mathrm{~g}$ of $\mathrm{Na}$ ). ${ }^{2}$

Thereby, a voluntary agreement was signed in 2010 between the Government of Brazil and the Brazilian Association of Food Industries (ABIA) to reduce the sodium content in sixteen categories of processed foods, being Brazilian cream cheese a member of this list. This agreement aims to minimize the excessive consumption of salt, which is associated with a number of chronic diseases such as hypertension, heart disease, kidney problems and cancer. ${ }^{3}$

Among the equipaments used for metal analysis, the microwave induced plasma optical emission spectrometer (MIP OES) is unique because of its low gas consumption and it provides good sensitivity for a number of elements and is inexpensive and easy to operate Matusiewicz. ${ }^{4}$ Different plasma gases has been used in MIP-OES technique, such as argon Brown ${ }^{5}$ or helium Murillo, ${ }^{6}$ but the use of nitrogen $\mathrm{Arai}^{7}$ (generating from atmospheric air) allowed significantly decrease the operating costs and made the technique competitive to inductively coupled plasma based techniques. Supplying the nitrogen gas from a generator instead of bottles or liquid storing systems can cut the analytical cost even more Karlsson. ${ }^{8}$ The advantage of MIPAES over flame atomic absorption spectrometry (F AAS) is that the analytes can be analysed simultaneously, there is no flammable and toxic gases (e.g. acetylene, nitrogen peroxide) as well as no manual handling of gas-cylinders in the laboratory. ${ }^{9}$

*e-mail: adriane.mn@hotmail.com
Brazilian cream cheese, because it is a complex matrix with high content of organic compounds, requires treatment prior to analysis. ${ }^{10}$ Conventional sample preparation methods for the determination of minerals in organic samples by spectrometric techniques usually involve acidic decomposition at high temperatures by the dry process and wet process in an open system, which is related to possible losses of analytes, the necessity of replacement of the acidic medium, in addition to contamination problems. ${ }^{11-13}$

A promising alternative which overcome these limitations related to the classical methods of sample preparation is based on the acid decomposition under reflux system, which was developed and applied by Ferreira et al. ${ }^{14}$ In order to increase the system efficiency, Oreste et al. ${ }^{15}$ developed a new design of the reflux system for commercial systems, which allows continuous recirculation of cold water, thus promoting the condensation of acid and the reflux, thereof supporting decomposition and avoiding loss of acid and volatile elements. This system allows the use of temperatures above the boiling point of the acids, which leads to an increase of the turbulence in the system, promoting heat transfer, thereby increasing the efficiency of the method. Its applicability has been shown in the preparation of different types of matrices for subsequent determination of metals by different analytical techniques. ${ }^{16-18}$

Another simple and efficient alternative used for the preparation of organic samples employs solubilization with tetramethylammonium hydroxide (TMAH). Samples treated with TMAH provides a solution with characteristics similar to a suspension, with a low dilution factor and remaining stable for months at room temperature. ${ }^{19}$ Ribeiro et al..${ }^{20}$ and Nobrega et al.. ${ }^{21}$ used the solubilization with TMAH in milk samples for determination of various elements by ICP OES and ICP MS.

Considering the lack of a sample preparation procedure that is proven suitable for Brazilian cream cheese and valuing convenience, speed and efficiency, this study aims to develop and evaluate two sample preparation procedures: acid decomposition, using mixture of $\mathrm{HNO}_{3} / \mathrm{H}_{2} \mathrm{SO}_{4}$ in a reflux system, and alkaline solubilization system with TMAH, for subsequent determination of $\mathrm{Na}, \mathrm{K}, \mathrm{Ca}$ and $\mathrm{Mg}$ in 
Brazilian cream cheese samples by atomic spectrometric techniques, MIP OES and F AAS/AES for comparision. The procedures were optimized using central composite design to assess the significance of the variables and thus establish the best working conditions for all analytes.

\section{EXPERIMENTAL}

\section{Apparatus and instrumental parameters}

The determinations of $\mathrm{Na}, \mathrm{K}, \mathrm{Ca}$ and $\mathrm{Mg}$ were carried out using a flame atomic absorption/emission spectrophotometer (F AAS/ AES) AAnalyst 200 (Perkin Elmer, Connecticut, EUA), with flame composed of compressed air with a flow rate of $10 \mathrm{~L} \mathrm{~min}^{-1}$ and acetylene gas $99.7 \%$ (Linde, São Paulo, Brazil) with flow of $2.5 \mathrm{~L}$ $\mathrm{min}^{-1}$. The equipment operates in emission mode for $\mathrm{Na}$ and $\mathrm{K}$ and in absorption mode for $\mathrm{Ca}$ and $\mathrm{Mg}$, which require the use of hollow cathode lamp (Perkin Elmer, Singapore). Background correction with deuterium arc lamp was used for Mg determination. FAAS/AES was operated using the working conditions described in Table 1.

Table 1. Operational conditions for $\mathrm{Na}, \mathrm{K}, \mathrm{Ca}$ and $\mathrm{Mg}$ determination by $\mathrm{F}$ AAS/AES and MIP OES

\begin{tabular}{lcccc}
\hline \multirow{2}{*}{ Parameters } & \multicolumn{4}{c}{ Analyte } \\
\cline { 2 - 5 } & $\mathrm{Na}$ & $\mathrm{K}$ & $\mathrm{Ca}$ & $\mathrm{Mg}$ \\
\hline Wavelength (nm) & 589.00 & 766.49 & 422.67 & 285.21 \\
Lamp current (mA) & - & - & 10 & 6 \\
Spectral band pass (mm) & 1.8 & 2.7 & 2.7 & 2.7 \\
\hline & \multicolumn{5}{c}{ MIP OES } \\
\hline Wavelength (nm) & 588.995 & 766.491 & 393.366 & 285.995 \\
Viewing position & 0 & 10 & 10 & 0 \\
Nebulizer flow (L/min) & 1 & 1 & 0.65 & 0.8 \\
\hline
\end{tabular}

For the robustness evaluation of the proposed procedures, the four elements were determined by an Agilent 4200 Microwave Plasma Atomic Emission Spectrometer (MIP OES) model (Agilent Technologies, Melbourne, Australia) equipped with a nebulizer and a double-pass glass cyclonic spray chamber (Agilent Technologies, Melbourne, Australia). This new equipment works with nitrogen plasma extracted from the air by a 4107 Nitrogen Generator (Agilent Technologies, Melbourne, Australia). Torch alignment and wavelength calibration for each analyte were carried out using a wavelength calibration solution for each medium $\left(\mathrm{HNO}_{3} / \mathrm{H}_{2} \mathrm{SO}_{4}\right.$ and TMAH) and automatically optimized by the instrument with MP Expert Software program (version1.5.1.0, Agilent Technologies, Melbourne, Australia). Instrumental parameter used were respectively: pump speed $15 \mathrm{rpm}$, uptake time $15 \mathrm{~s}$, stabilization time $15 \mathrm{~s}$, read time 3 $\mathrm{s}$, number of replicates 3 and automatic background correction. The instrumental conditions depending on the analyte are described in Table 1.

In this work the samples were weighed using an Ohaus Adventurer analytical balance (Model AR 2140, Pine Brook, NJ, USA) with a resolution of $0.1 \mathrm{mg}$ and tare maximum of $210 \mathrm{~g}$. Moisture was determined in an oven (model 1.2, Odontobras, São Paulo, Brazil).

For the sample preparation by acid decomposition $\left(\mathrm{HNO}_{3} / \mathrm{H}_{2} \mathrm{SO}_{4}\right)$, a heated digestor block (MA-4025 from Marconi, Piracicaba, SP, Brazil) was used. The reflux system consists of a glass digester tube closed with a small glass tube $(17 \mathrm{~cm})$ and filled with continuous cold water recirculation, controlled at $15^{\circ} \mathrm{C}$ by a thermostatic bath Model Q-214M2 (Marconi, Piracicaba, SP, Brazil). This system adapted by Oreste et al. ${ }^{15}$ promotes the acids recirculation within the bigger tube $(25 \mathrm{~cm})$ and avoid losses by volatilization of the analytes and reagents during the decomposition.

For the decomposition by dry method (Reference method) a muffle furnace model Q-318.24 (Quimis, São Paulo, Brazil) was used and the final ashes were solubilized in a heating plate model $752 \mathrm{~A}$ (Fisatom, São Paulo, Brazil).

\section{Reagents and solutions}

Analytical reagent grade materials were used for all the experiments: nitric acid 65\% (w/w), hydrochloric acid 36.5\% (w/w) (Synth, São Paulo, Brazil), sulfuric acid 98\% (w/w) (Vetec, Rio de Janeiro, Brazil), tetramethylammonium hydroxide $25 \%(\mathrm{w} / \mathrm{v})$ in water (Sigma Aldrich, Seelze, Germany). Samples and standards were prepared with deionized water obtained by a water distiller MA078 (Marconi, São Paulo, Brazil) and subsequently deionized by passing through a column CS1800 (Permution, Curitiba, Brazil). Nitric acid $65 \%(\mathrm{v} / \mathrm{v})$ and hydrochloric acid $36.5 \%(\mathrm{w} / \mathrm{w})$ were purified by double subboiling distillation in a quartz system MA-075 (Marconi, São Paulo, Brazil). All glass containers and laboratorial materials were washed and decontaminated by immersion in $10 \% \mathrm{v} / \mathrm{v} \mathrm{HNO}_{3}$ for at least $48 \mathrm{~h}$, rinsed with deionized water and dried.

The standard solutions of the analytes were diluted with deionized water from stock solutions (Fluka, Buchs, Germany) containing $10.000 \mathrm{mg} \mathrm{L}^{-1}$ of $\mathrm{Na}, \mathrm{K}$ and $\mathrm{Mg}$, and $1.000 \mathrm{mg} \mathrm{L}^{-1}$ of Ca. Calibration curves were constructed from these solutions in concentrations ranging between 0.25 and $1.5 \mathrm{mg} \mathrm{L}^{-1}$ to $\mathrm{Na}$ and $\mathrm{K}, 1$ and $4 \mathrm{mg} \mathrm{L}^{-1}$ for $\mathrm{Ca}$, and 0.1 and $0.4 \mathrm{mg} \mathrm{L}^{-1}$ for $\mathrm{Mg}$, and the medium was the same for the samples.

\section{Samples}

Brazilian cream cheese type cheddar brand A (Sample 1), traditional Brazilian cream cheese brand A and B (Sample 2 and 3), light Brazilian cream cheese (reduced fat amount) brand A and B (Sample 4 and 5) and light Brazilian cream cheese (reduced fat and sodium amount) brand B (Sample 6), all acquired in the local market of the city of Pelotas-RS, Brazil. The samples were stored under freezing conditions $\left(-18^{\circ} \mathrm{C}\right)$ during the study period, being thawed and homogenized prior to analysis.

\section{Sample preparation procedures}

\section{Procedure 1: Acid decomposition using reflux system}

The analysis was performed by weighing $875 \mathrm{mg}$ of the sample directly in the digestion tubes, then $5 \mathrm{~mL}$ of $\mathrm{HNO}_{3}$ and $3 \mathrm{~mL}$ of $\mathrm{H}_{2} \mathrm{SO}_{4}$ were added. The reflux system was coupled to digestion tubes, which were heated in the digester block at a temperature of $325^{\circ} \mathrm{C}$, and the decomposition time was $3 \mathrm{~h}$. The independent variables sample mass, $\mathrm{H}_{2} \mathrm{SO}_{4}$ volume, temperature of the digester block and decomposition time, were optimized using experimental design. After cooling, the decomposed samples were transferred to polypropylene vials and adjusted to $50 \mathrm{ml}$ with deionized water.

\section{Procedure2: Alkaline solubilization with $T M A H$}

For alkaline solubilization, $300 \mathrm{mg}$ of the sample were weighed directly into polypropylene vials, followed by addition of $100 \mu \mathrm{L}$ of TMAH, standing overnight (approximately 12 hours) at room temperature. After this period, the vials were adjusted at $50 \mathrm{~mL}$ with deionized water. 
Procedure 3: Dry decomposition

In order to evaluate the proposed procedures for the analysis of $\mathrm{Na}, \mathrm{K}, \mathrm{Ca}$ and $\mathrm{Mg}$, the sample was treated by reference methodology and the results were compared by statistical tests. This procedure used was described by Adolfo Lutz Institute of Brazil. ${ }^{12}$

\section{Preliminary studies and methodology}

The moisture content was determined using the method described by Adolfo Lutz Institute of Brazil. ${ }^{12}$ The average percentages of moisture found for the six samples analyzed were respectively $65.0 \%$ for sample $1,67.0 \%$ for sample 2 and $3,75.0 \%$ for sample 4 and 5 and $70 \%$ for sample 6 . This study aimed to define the sample with the highest amount of dry matter (lower moisture content) for development of the procedures. Sample 1 has the highest quantity of dry matter, and also presents higher content of fat and proteins, information obtained by the product label. Thus, because it is a more complex matrix, this sample was used for the development of the proposed sample preparation procedures.

Procedure 3 was conducted in order to verify the accuracy of procedures 1 and 2 , which were optimized using an experimental design.
After checking the accuracy, the procedures were applied to other samples (sample 2, sample 3, sample 4, sample 5 and sample 6), and the four analyte concentrations were compared using two analytical techniques, F AAS/AES and MIP OES.

To evaluate the influence of variables related to the sample preparation stage for subsequent determination of the analytes under study, a central composite design (CCD) with response surface methodology (RSM) was performed. This influence was evaluated using Statistica software version 8.0 for Windows (Tulsa, OK, USA).

The independent variables for procedure 1 (acid decomposition under reflux system) were sample mass (500 to $1000 \mathrm{mg}$ ), $\mathrm{H}_{2} \mathrm{SO}_{4}$ volume ( 1 to $3 \mathrm{~mL}$ ), temperature of the digester block $\left(280\right.$ to $340{ }^{\circ} \mathrm{C}$ ) and decomposition time ( 1 to $3 \mathrm{~h}$ ), totaling 27 assays ( $2^{4}$ with 3 central points and 8 axial points), and to procedure 2 (alkaline solubilization with TMAH), sample mass (50 to $300 \mathrm{mg}$ ) and volume of TMAH (100 to $500 \mu \mathrm{L}$ ), totaling 11 assays $\left(2^{2}\right.$ with 3 central points and 4 axial points). Tables 2 and 3 show the variables and levels used in the factorial design. It should be noted that the assays were performed in triplicate.

The accuracy of procedures 1 and 2 was evaluated by recovery tests and by comparison of methods with the reference method

Table 2. CCD matrix for determination of $\mathrm{Na}, \mathrm{K}, \mathrm{Ca}$ and $\mathrm{Mg}$ in Brazilian cream cheese by F AAS/AES after acid decomposition with reflux system

\begin{tabular}{|c|c|c|c|c|c|c|c|c|}
\hline \multirow[b]{2}{*}{ Runs } & \multicolumn{4}{|c|}{ Independent variables } & \multicolumn{4}{|c|}{ Analytical signals } \\
\hline & $\begin{array}{c}\text { Sample } \\
\text { mass (mg) }\end{array}$ & $\begin{array}{c}\mathrm{H}_{2} \mathrm{SO}_{4} \\
\text { volume }(\mathrm{mL})\end{array}$ & Time (h) & $\begin{array}{c}\text { Temperature } \\
\left({ }^{\circ} \mathrm{C}\right)\end{array}$ & $\mathrm{Na}^{*}$ & $\mathrm{~K}^{*}$ & $\mathrm{Ca}^{* *}$ & $\mathrm{Mg}^{* *}$ \\
\hline 1 & 625 & 1.5 & 1.5 & 295 & 2071667 & 165175 & 0.579 & 1.108 \\
\hline 2 & 875 & 1.5 & 1.5 & 295 & 2626467 & 233590 & 0.710 & 1.282 \\
\hline 3 & 625 & 2.5 & 1.5 & 295 & 2097800 & 164985 & 0.645 & 1.047 \\
\hline 4 & 875 & 2.5 & 1.5 & 295 & 2725867 & 234060 & 0.692 & 1.263 \\
\hline 5 & 625 & 1.5 & 2.5 & 295 & 2070067 & 169275 & 0.721 & 1.083 \\
\hline 6 & 875 & 1.5 & 2.5 & 295 & 2607333 & 235405 & 0.699 & 1.271 \\
\hline 7 & 625 & 2.5 & 2.5 & 295 & 2068867 & 166415 & 0.629 & 1.067 \\
\hline 8 & 875 & 2.5 & 2.5 & 295 & 2549067 & 230155 & 0.693 & 1.269 \\
\hline 9 & 625 & 1.5 & 1.5 & 325 & 2055133 & 173995 & 0.638 & 1.069 \\
\hline 10 & 875 & 1.5 & 1.5 & 325 & 2595667 & 240030 & 0.678 & 1.286 \\
\hline 11 & 625 & 2.5 & 1.5 & 325 & 1893800 & 172175 & 0.648 & 1.076 \\
\hline 12 & 875 & 2.5 & 1.5 & 325 & 2350000 & 235395 & 0.689 & 1.275 \\
\hline 13 & 625 & 1.5 & 2.5 & 325 & 2043533 & 170880 & 0.727 & 1.094 \\
\hline 14 & 875 & 1.5 & 2.5 & 325 & 2515733 & 236395 & 0.708 & 1.307 \\
\hline 15 & 625 & 2.5 & 2.5 & 325 & 2025733 & 175680 & 0.632 & 1.060 \\
\hline 16 & 875 & 2.5 & 2.5 & 325 & 2612067 & 236945 & 0.702 & 1.282 \\
\hline 17 & 500 & 2.0 & 2.0 & 310 & 1624133 & 132710 & 0.591 & 0.954 \\
\hline 18 & 1000 & 2.0 & 2.0 & 310 & 3043533 & 262250 & 0.756 & 1.357 \\
\hline 19 & 750 & 1.0 & 2.0 & 310 & 2295200 & 194975 & 0.687 & 1.208 \\
\hline 20 & 750 & 3.0 & 2.0 & 310 & 2715000 & 208520 & 0.658 & 1.222 \\
\hline 21 & 750 & 2.0 & 1.0 & 310 & 2440800 & 203325 & 0.611 & 1.191 \\
\hline 22 & 750 & 2.0 & 3.0 & 310 & 2304800 & 197077 & 0.766 & 1.224 \\
\hline 23 & 750 & 2.0 & 2.0 & 280 & 2173133 & 203085 & 0.609 & 1.171 \\
\hline 24 & 750 & 2.0 & 2.0 & 340 & 2090933 & 207760 & 0.792 & 1.187 \\
\hline 25 & 750 & 2.0 & 2.0 & 310 & 2403200 & 211215 & 0.654 & 1.211 \\
\hline 26 & 750 & 2.0 & 2.0 & 310 & 2389300 & 203895 & 0.659 & 1.211 \\
\hline 27 & 750 & 2.0 & 2.0 & 310 & 2342000 & 200145 & 0.613 & 1.206 \\
\hline
\end{tabular}

* Emission signal; ** Absorbance signal. 
Table 3. CCD matrix for determination of $\mathrm{Na}, \mathrm{K}, \mathrm{Ca}$ and $\mathrm{Mg}$ in Brazilian cream cheese by F AAS/AES after solubilization with TMAH

\begin{tabular}{|c|c|c|c|c|c|c|}
\hline \multirow{2}{*}{ Runs } & \multicolumn{2}{|c|}{ Independent variables } & \multicolumn{4}{|c|}{ Analytical signals } \\
\hline & Sample mass (mg) & TMAH volume $(\mu \mathrm{L})$ & $\mathrm{Na}^{*}$ & $\mathrm{~K}^{*}$ & $\mathrm{Ca}^{* *}$ & $\mathrm{Mg}^{* *}$ \\
\hline 1 & 85 & 160 & 291909.667 & 455442.000 & 0.160 & 0.196 \\
\hline 2 & 265 & 160 & 457286.667 & 830612.000 & 0.368 & 0.360 \\
\hline 3 & 85 & 440 & 304107.333 & 459740.667 & 0.131 & 0.190 \\
\hline 4 & 265 & 440 & 470893.000 & 859429.000 & 0.314 & 0.353 \\
\hline 5 & 50 & 300 & 245049.333 & 359873.667 & 0.100 & 0.162 \\
\hline 6 & 300 & 300 & 488353.000 & 8989913.667 & 0.337 & 0.369 \\
\hline 7 & 175 & 100 & 404649.000 & 702303.333 & 0.247 & 0.283 \\
\hline 8 & 175 & 500 & 407580.000 & 697333.667 & 0.212 & 0.281 \\
\hline 9 & 175 & 300 & 406746.667 & 703159.333 & 0.212 & 0.270 \\
\hline 10 & 175 & 300 & 405201.333 & 677741.334 & 0.193 & 0.257 \\
\hline 11 & 175 & 300 & 407749.000 & 689217.333 & 0.191 & 0.259 \\
\hline
\end{tabular}

* Emission signal; ** Absorbance signal.

(procedure 3). For the first test, after obtaining the optimum conditions of the variables, procedures 1 and 2 were performed by adding known concentrations of the analytes to sample 1 and the percent recovery was calculated at the end of each analysis.

The limits of detection of the proposed methods (LOD) (3 times the standard deviation of 10 signals of the white of the calibration curve divided by the slope of the curve) were analyzed, as well as accuracy through repeatability, being expressed by standard deviations (RSD\%).

\section{RESULTS AND DISCUSSION}

\section{Experimental design}

The results obtained by the CCD (Tables 2 and 3) showed, through

A

\begin{tabular}{|c|c|}
\hline \multirow{3}{*}{$\begin{array}{r}\text { (1) Sample mass }(\mathrm{mg})(\mathrm{L}) \\
\text { Temperature }\left({ }^{\circ} \mathrm{C}\right)(\mathrm{Q}) \\
\text { (4)Temperature }\left({ }^{\circ} \mathrm{C}\right)(\mathrm{L})\end{array}$} & \multirow[b]{2}{*}{$-2,52541$} \\
\hline & \\
\hline & $-1,49595$ \\
\hline 3Lby4L & \multirow{2}{*}{$\begin{array}{l}1,089024 \\
1,022346\end{array}$} \\
\hline $\mathrm{H}_{2} \mathrm{SO}_{4}$ volume $(\mathrm{mL})(\mathrm{Q})$ & \\
\hline (2) $\mathrm{H}_{2} \mathrm{SO}_{4}$ volume $(\mathrm{mL})(\mathrm{L})$ & 0,9703275 \\
\hline 2Lby4L & $-0,812307$ \\
\hline 2Lby3L & 0,6187739 \\
\hline Sample mass $(\mathrm{mg})(\mathrm{Q})$ & $-0,60635$ \\
\hline (3)Time (h)(L) & $-0,329496$ \\
\hline 1Lby4L & $-0,298675$ \\
\hline Time $(h)(Q)$ & $-0,235786$ \\
\hline 1Lby3L & $-0,213305$ \\
\hline \multicolumn{2}{|r|}{0,09471118} \\
\hline \multicolumn{2}{|r|}{$p=, 05$} \\
\hline & Standardized Effect Estimate (Absolute Value) \\
\hline
\end{tabular}

C

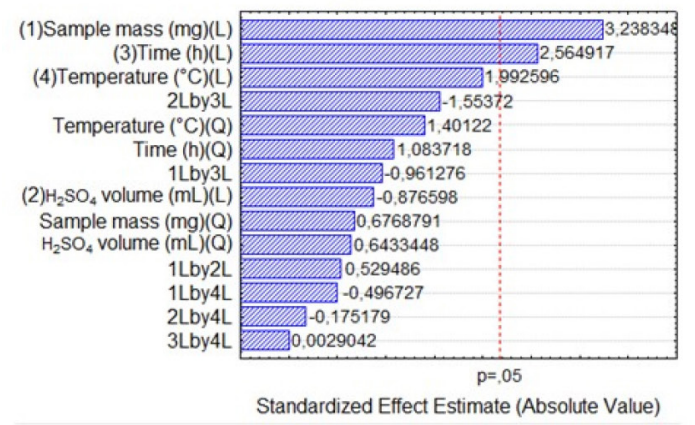

Pareto chart, which were the variables that presented significant influence in the determination of $\mathrm{Na}, \mathrm{K}, \mathrm{Ca}$ and $\mathrm{Mg}$. According to Figure 1, which shows the Pareto chart for the four analytes obtained using procedure 1 , it was observed that the variable sample mass was significant for all analyte determinations. However, the variable temperature is significant for the determination of Na (Figure 1A), $\mathrm{K}$ (Figure 1B) and $\mathrm{Mg}$ (Figure 1D), whereas the decomposition time was significant only for Ca (Figure 1C).

The same evaluation was made for the procedure 2. Figure 2 shows, through Pareto chart, that sample mass is a significant variable in the determination of $\mathrm{Na}$ (Figure 2A), $\mathrm{Ca}$ (Figure 2C) and $\mathrm{Mg}$ (Figure 2D), and TMAH volume in the determination of $\mathrm{Ca}$ (Figure 2C) and $\mathrm{Mg}$ (Figure 2D). For determination of $\mathrm{K}$ (Figure 2B), none of the variables were significant at $95 \%$ confidence level.

\section{B}

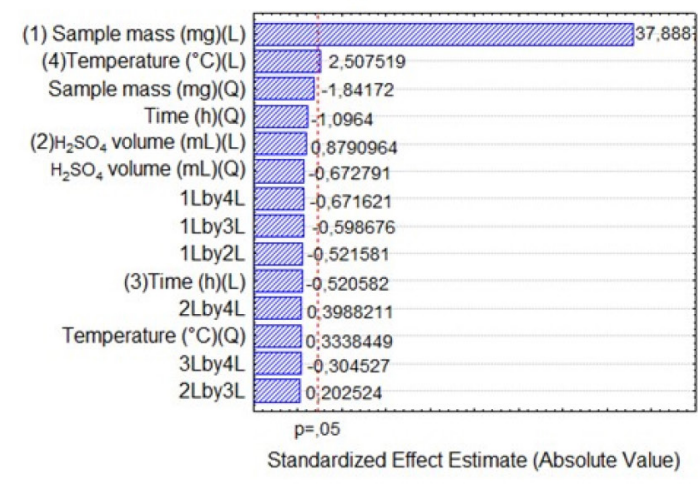

D

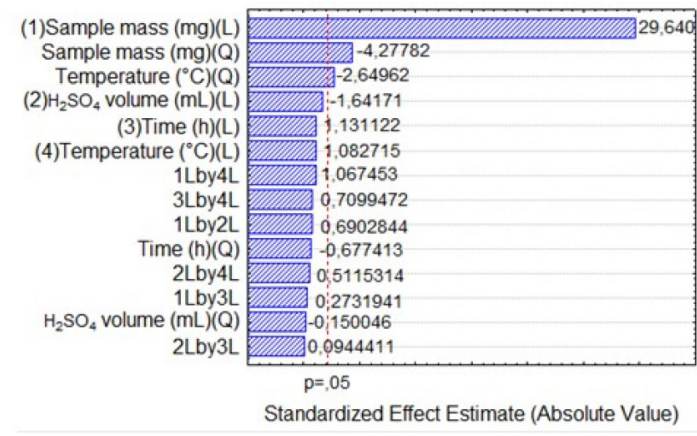

Figure 1. Pareto chart for acid decomposition with reflux system for determination of $N a(A), K(B), C a(C)$ and $M g(D)$ by $F$ AAS/AES 
A

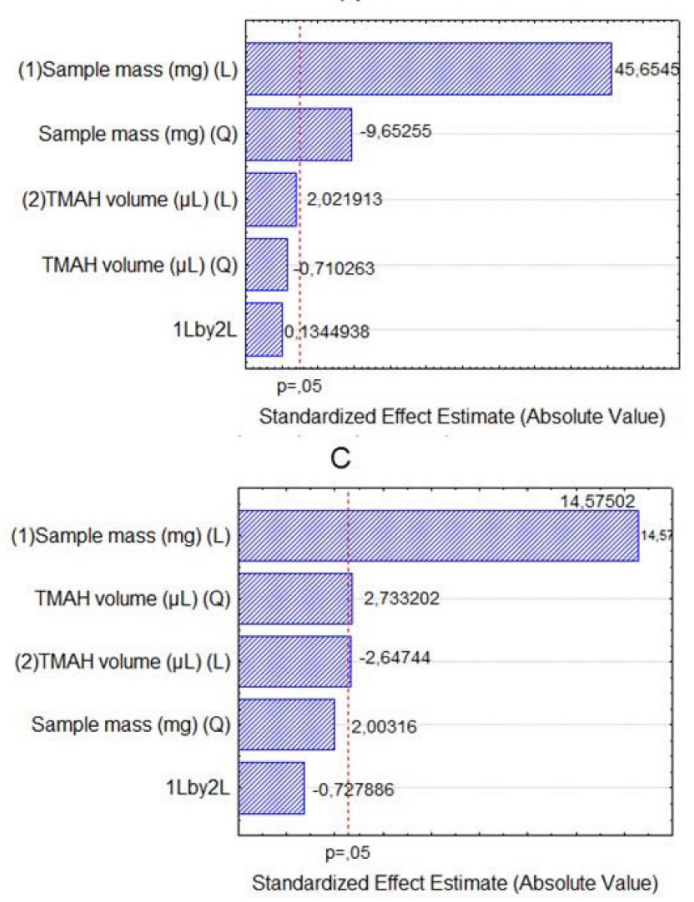

B

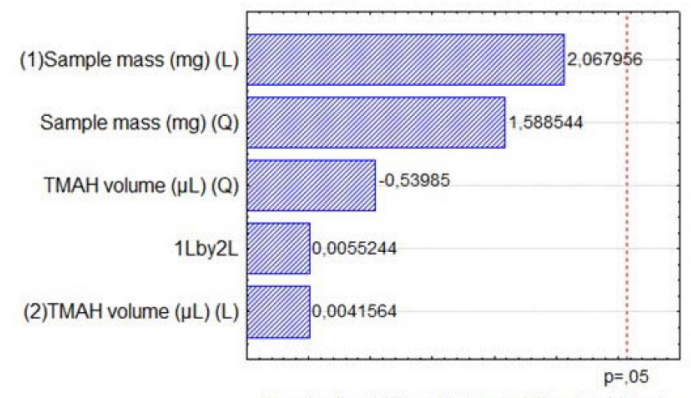

Standardized Effect Estimate (Absolute Value)

D

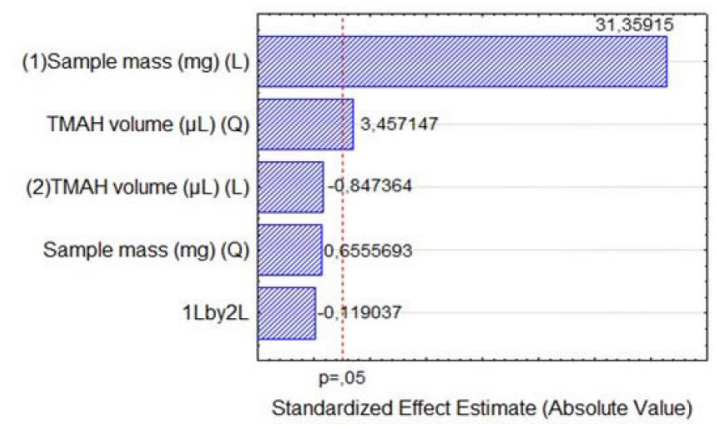

Figure 2. Pareto chart for solubilization with TMAH in determining of $\mathrm{Na}(\mathrm{A}), \mathrm{K}(\mathrm{B}), \mathrm{Ca}(\mathrm{C})$ and $\mathrm{Mg}(\mathrm{D})$ by $\mathrm{F}$ AAS/AES

The analysis of variance (ANOVA) were made considering only the significant variables, and for both procedures the models were adequate to describe the results, enabling generate response surfaces graphics. The response surfaces graphics for the procedures 1 and 2 are shown in Figures 3 and 4, respectively.

The influence of mass variable for the elements after acid decomposition is presented in the Figure 3. The surface response of Figure 3A shows that the highest signals obtained for $\mathrm{Na}$ was achieved when used mass in the range of 625 to $875 \mathrm{mg}$. For the other analytes, higher mass provided the greatest signs. Thus, $875 \mathrm{mg}$ was chosen for the study, assuring adequate sensitivity for analysis of the respective analytes.

For variable temperature, the surfaces of Figure $3 \mathrm{~A}$ and $3 \mathrm{D}$ show that the highest signals for $\mathrm{Na}$ and $\mathrm{Mg}$, respectively, are between 295 and $325^{\circ} \mathrm{C}$. However, for the K (Figure 3B) at higher temperature results in highest signal, which is in agreement with the literature, since the acid decomposition of samples that have high amount of fat and protein, require temperatures around $300{ }^{\circ} \mathrm{C}$ for greater efficiency in breaking carbon-carbon bonds of organic molecules. ${ }^{13,22,23}$ The variable time was statistically significant only for Ca determination. The surface response graphic of Figure $3 \mathrm{C}$ shows that, in this case, the highest decomposition time was necessary to determine that element, since about 70 to $80 \%$ of $\mathrm{Ca}$ in milk is bound to the casein micelle. ${ }^{24}$

De La Fuente and Juárez ${ }^{25}$ reported that calcium associated with the casein micelles in the presence of fat difficults the determination of this element in milk samples. Würfles et al..$^{22}$ reported in their studies that it is recommended acid decomposition at $300{ }^{\circ} \mathrm{C}$ to completely oxidize biological samples, regardless of chemical composition. At this temperature, decomposition after $2 \mathrm{~h}$, the resulting solution contains practically no carbon $(99.9 \%$ of the original content in the sample are oxidized carbon). Possibly, due to the complex structure of the casein micelle, higher temperature and time for this sample decomposition are required. However, due to the relatively low boiling point of $\mathrm{HNO}_{3}\left(120^{\circ} \mathrm{C}\right)$, decomposition with a mixture of $\mathrm{HNO}_{3}$ and $\mathrm{H}_{2} \mathrm{SO}_{4}$ (boiling point $339^{\circ} \mathrm{C}$ ) is recommended, which allows to work with higher temperatures by increasing the decomposition efficiency, especially in high-fat samples. ${ }^{26}$

The variable $\mathrm{H}_{2} \mathrm{SO}_{4}$ volume was not significant, however, in the preliminary tests it was observed that the decomposition carried out with mixture of acids $\left(\mathrm{HNO}_{3}\right.$ and $\left.\mathrm{H}_{2} \mathrm{SO}_{4}\right)$ has better analytical signals in the determination of the four elements compared with the use of only $\mathrm{HNO}_{3}$. The same was verified by Oreste et al. ${ }^{17}$ by using the mixture in order to determine $\mathrm{Ca}, \mathrm{Cu}, \mathrm{Fe}, \mathrm{K}$ and $\mathrm{Na}$ milk powder samples.

During the tests it was observed that the decomposition using acid mixture with volumes of 1 and $2 \mathrm{~mL} \mathrm{H}_{2} \mathrm{SO}_{4}$ showed an oily residue after the decomposition, which was not observed when using $3 \mathrm{~mL}$ of acid. Thus, the volume of $3 \mathrm{~mL}$ was chosen to avoid interference during analysis, especially in the nebulization F AAS/ AES and MIP OES.

At the end of this study, the optimal condition for the procedure 1 was: $875 \mathrm{mg}$ of sample, $3 \mathrm{~mL}$ of $\mathrm{H}_{2} \mathrm{SO}_{4} 5 \mathrm{~mL}$ of $\mathrm{HNO}_{3}$, block temperature of $325^{\circ} \mathrm{C}$ and $3 \mathrm{~h}$ of time decomposition.

The response surfaces graphics presented in Figure 4 shows that for the solubilization with TMAH, as in procedure 1, there was an influence of the increase in mass of the sample in obtaining higher signals for $\mathrm{Na}, \mathrm{Ca}$ and $\mathrm{Mg}$.

For Na (Figure 4A), the larger mass provided the highest signals, regardless of the volume of TMAH used. For $\mathrm{Ca}$ (Figure 4B) and $\mathrm{Mg}$ (Figure 4C), the smaller volume of the reagent showed higher signals. In this study we show that small amounts of TMAH are needed in the sample solubilization, which is consistent with the predicted by Matusiewicz et al. ${ }^{4}$ and Nobrega et al. ${ }^{21}$ Thus, targeting a lower reagent consumption and consequently a smaller waste generation, the TMAH volume of $100 \mu \mathrm{L}$ was fixed. Therefore, the optimal condition for the alkaline solubilization was: $500 \mathrm{mg}$ of sample in the presence of $100 \mu \mathrm{L}$ TMAH.

\section{Evaluation of proposed procedures}

In this work for evaluation of proposed procedures for sample 
A

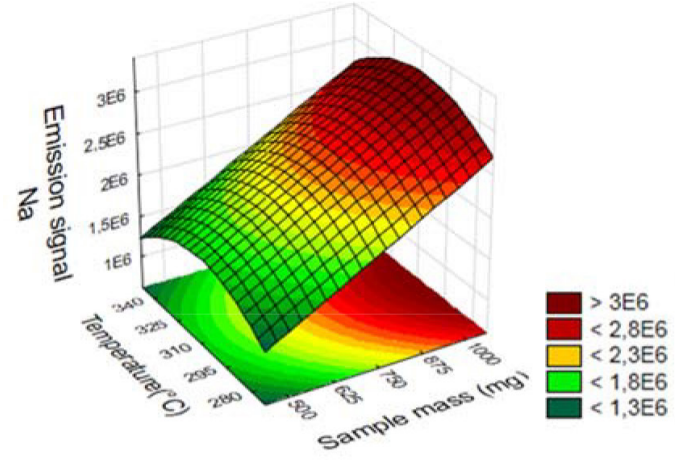

C

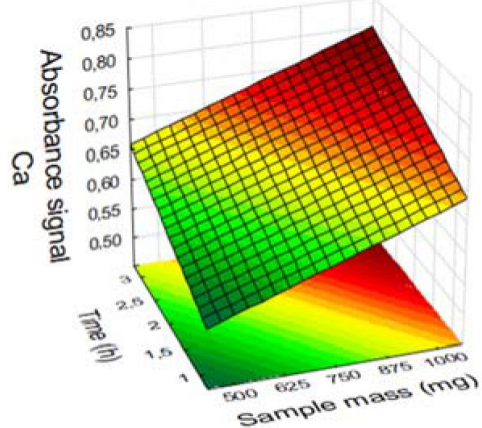

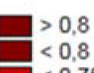

$<0.75$

$<0.7$

$<0.65$
$-<0.6$

$<0,6$
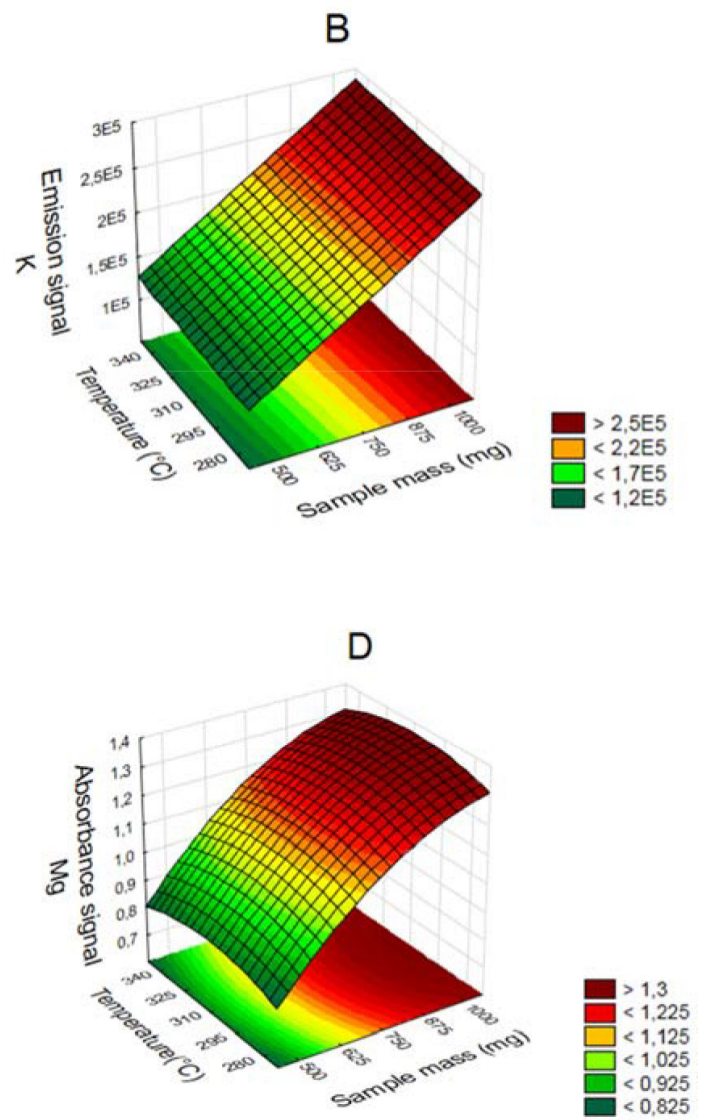

Figure 3. Surface response graphics to acid decomposition under reflux system for determination of $N a(A), K(B), C a(C)$ and $M g(D)$ by $F$ AAS/AES depending on the sample mass, temperature and time

A

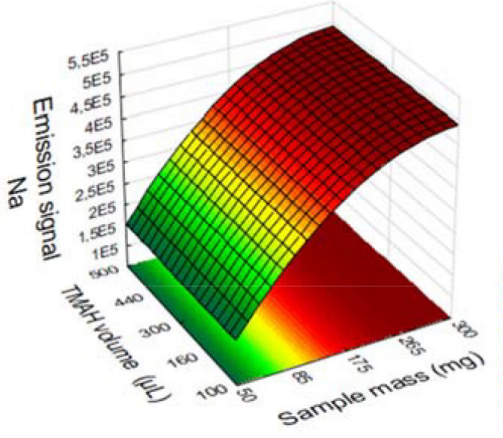

B

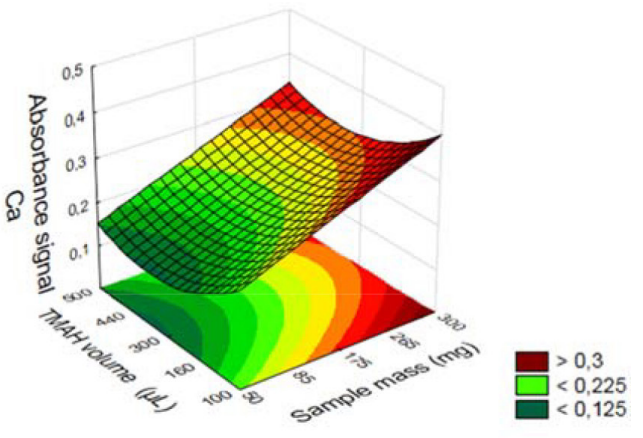

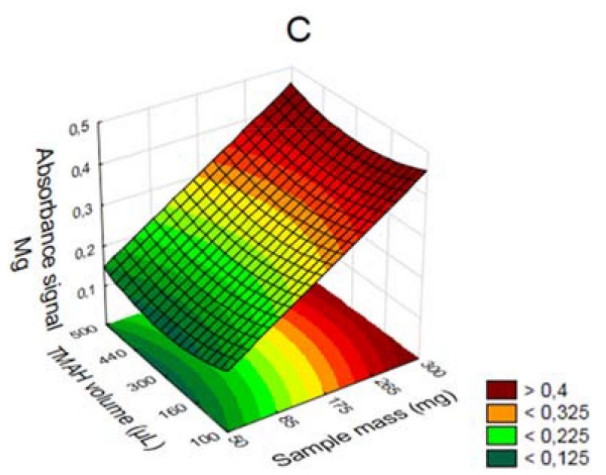

Figure 4. Surface response graphics for solubilization with TMAH for determination of $\mathrm{Na}(\mathrm{A}), \mathrm{Ca}(\mathrm{B})$ and $\mathrm{Mg}(\mathrm{C})$ for $\mathrm{F}$ AAS/AES depending on the sample mass and TMAH volume 
Table 4. Concentrations of $\mathrm{Na}, \mathrm{K}, \mathrm{Ca}$ and $\mathrm{Mg}\left(\mathrm{mg} \mathrm{g}^{-1}\right)$ by F AAS/AES before and after different concentrations additions of the respective analytes in the sample 1 for acid decomposition under reflux system and solubilization with TMAH

\begin{tabular}{|c|c|c|c|c|c|c|}
\hline & \multicolumn{3}{|c|}{ Acid decomposition } & \multicolumn{3}{|c|}{ Solubilization with TMAH } \\
\hline & $\begin{array}{l}\text { Added value } \\
\qquad\left(\mathrm{mg} \mathrm{g}^{-1}\right)\end{array}$ & $\begin{array}{l}\text { Found value* } \\
\qquad\left(\mathrm{mg} \mathrm{g}^{-1}\right)\end{array}$ & $\begin{array}{c}\text { Recovery } \\
(\%)\end{array}$ & $\begin{array}{l}\text { Added value } \\
\quad\left(\mathrm{mg} \mathrm{g}^{-1}\right)\end{array}$ & $\begin{array}{l}\text { Found value* } \\
\qquad\left(\mathrm{mg} \mathrm{g}^{-1}\right)\end{array}$ & $\begin{array}{c}\text { Recovery } \\
(\%)\end{array}$ \\
\hline \multirow{4}{*}{$\mathrm{Na}$} & 0.00 & $7.39 \pm 0.29$ & - & 0.00 & $7.18 \pm 0.08$ & - \\
\hline & 3.43 & $10.60 \pm 0.19$ & 94 & 2.50 & $9.78 \pm 0.06$ & 104 \\
\hline & 9.14 & $15.92 \pm 0.16$ & 93 & 6.67 & $13.29 \pm 0.11$ & 92 \\
\hline & 17.13 & $21.24 \pm 0.35$ & 81 & 10.00 & $16.15 \pm 0.09$ & 90 \\
\hline \multirow{4}{*}{ K } & 0.00 & $0.76 \pm 0.01$ & - & 0.00 & $0.75 \pm 0.03$ & - \\
\hline & 0.46 & $1.15 \pm 0.01$ & 85 & 0.75 & $1.49 \pm 0.04$ & 99 \\
\hline & 0.86 & $1.50 \pm 0.01$ & 86 & 2.00 & $2.82 \pm 0.06$ & 104 \\
\hline & 1.37 & $1.86 \pm 0.01$ & 80 & 3.67 & $3.69 \pm 0.02$ & 80 \\
\hline \multirow{4}{*}{$\mathrm{Ca}$} & 0.00 & $2.22 \pm 0.07$ & - & 0.00 & $1.98 \pm 0.01$ & - \\
\hline & 1.71 & $3.84 \pm 0.03$ & 95 & 5.00 & $6.68 \pm 0.03$ & 94 \\
\hline & 3.08 & $4.84 \pm 0.16$ & 85 & 8.30 & $9.08 \pm 0.01$ & 86 \\
\hline & 4.28 & $5.68 \pm 0.03$ & 81 & 11.70 & $13.88 \pm 0.08$ & 102 \\
\hline \multirow{4}{*}{$\mathrm{Mg}$} & 0.00 & $0.108 \pm 0.002$ & - & 0.00 & $0.11 \pm 0.01$ & - \\
\hline & 0.19 & $0.304 \pm 0.003$ & 103 & 0.13 & $0.24 \pm 0.01$ & 100 \\
\hline & 0.32 & $0.427 \pm 0.005$ & 100 & 0.21 & $0.320 \pm 0.01$ & 100 \\
\hline & 0.43 & $0.540 \pm 0.013$ & 100 & 0.29 & $0.40 \pm 0.01$ & 100 \\
\hline
\end{tabular}

* Values expressed as mean \pm standard deviation $(\mathrm{n}=3)$.

preparation of Brazilian cream cheese and subsequent determination of $\mathrm{Na}, \mathrm{K}, \mathrm{Ca}$ and $\mathrm{Mg}$ the methodologies were validated by recovery tests. Table 4 shows the concentrations and the percentage of recoveries obtained by FAAS and FAES for the proposed procedures.

According to the results, the recovery percentages were in satisfactory ranges, between $80-103 \%$ for procedure 1 , and $80-104 \%$ for procedure 2 , which proves the accuracy of both procedures. These results are in accordance with established by the US-FDA. ${ }^{27}$

Besides the recovery tests, the accuracy of the proposed methods was also confirmed by comparing the results with the reference method recommended by the Instituto Adolfo Lutz (Procedure 3). Table 5 shows the concentrations of the elements $\mathrm{Na}, \mathrm{K}, \mathrm{Ca}$ and $\mathrm{Mg}$ obtained in sample $1\left(\mathrm{mg} \mathrm{g}^{-1}\right)$, after the samples preparation from the three procedures and determination by FAAS/AES.

According to the results reported in the respective Table 5, a good agreement can be observed at concentrations of all analytes, regardless of sample preparation method. By applying the Tukey test, it was possible to prove that there is no significant difference to a $95 \%$ confidence level in determining the analytes between the proposed methods and the conventional method.

The accuracy of the proposed procedures was evaluated through the RSD values obtained from nine replicates (Table 5). It can be seen that these values are between 0.38 and 6.40 , which demonstrates the good repeatability of the procedure, since they are below $10 \%$.

The four analytes were determined by the new MIP OES technique, checking if the preparation procedures of Brazilian cream cheese samples would be suitable for this technique, since works with nitrogen plasma generated by microwave, which has temperatures of around $6000{ }^{\circ} \mathrm{C}$, becoming more susceptible to interferences during the elements excitation. Moreover, this study is relevant because this technique has great potential for routine analysis, since the operating cost is greatly reduced.

The figures of merit for the techniques, as well as calibration curves of all elements are in Table 6. It was found that the calibration
Table 5. Average concentration of the elements $\left(\mathrm{mg} \mathrm{g}^{-1}\right) \mathrm{Na}, \mathrm{K}, \mathrm{Ca}$ and $\mathrm{Mg}$ in sample 1 after the three sample preparations and determination by F AAS/AES

\begin{tabular}{lccc}
\hline Analyte & Procedure & $\begin{array}{c}\text { Concentration } \\
\left(\mathrm{mg} \mathrm{g}^{-1}\right) \pm \mathrm{SD}\end{array}$ & RSD \% \\
\hline \multirow{3}{*}{$\mathrm{Na}$} & 1 & $7.35 \pm 0.15$ & 2.04 \\
& 2 & $7.00 \pm 0.15$ & 2.14 \\
& 3 & $8.00 \pm 0.03$ & 0.38 \\
$\mathrm{~K}$ & 1 & $0.76 \pm 0.01$ & 1.32 \\
& 2 & $0.75 \pm 0.02$ & 2.67 \\
$\mathrm{Ca}$ & 3 & $0.80 \pm 0.01$ & 1.25 \\
& 1 & $2.23 \pm 0.01$ & 0.45 \\
& 2 & $1.98 \pm 0.05$ & 2.53 \\
$\mathrm{Mg}$ & 3 & $2.03 \pm 0.13$ & 6.40 \\
\hline & 1 & $0.108 \pm 0.002$ & 1.85 \\
& 2 & $0.110 \pm 0.002$ & 1.82 \\
\hline
\end{tabular}

Values expressed as mean \pm standard deviation $(n=9)$.

curves showed good linearity for the three techniques with R> 0.99 , regardless of the samples preparation procedure. Regarding the sensitivity obtained by the slope of the values of the calibration curves, the MIP OES technique was more sensitive in determining the elements. By analyzing the limits of detection (LOD), it may be noted that the sample preparation by acid decomposition with reflux system had the lowest LOD values for the four elements in both techniques, possibly because the method also allows the decomposition of full sample, compared to alkaline solubilization, hereby presenting the higher excitation of the elements, raising the signals, thus allowing detection of elements at lower concentrations. 
Table 6. Figures of merit of the techniques F AAS/AES and MIP OES for acid decomposition with reflux system and alkaline solubilization with TMAH

\begin{tabular}{|c|c|c|c|c|c|c|c|}
\hline Analyte & $\begin{array}{l}\text { Analytical } \\
\text { technique }\end{array}$ & Procedure & $\begin{array}{l}\text { Range } \\
\left(\mathrm{mgL}^{-1}\right)\end{array}$ & $\begin{array}{c}\mathrm{a} \\
\left(\mathrm{L} \mathrm{mg}^{-1}\right)\end{array}$ & $\mathrm{R}$ & $\begin{array}{c}\mathrm{LOD}^{*} \\
\left(\mathrm{mg} \mathrm{L}^{-1}\right)\end{array}$ & $\begin{array}{l}\mathrm{LOD}^{* *} \\
\left(\mu \mathrm{g} \mathrm{g}^{-1}\right)\end{array}$ \\
\hline \multirow{4}{*}{$\mathrm{Na}$} & \multirow{2}{*}{ F AES } & 1 & \multirow{2}{*}{$0.25-1.5$} & 14703.49 & 0.991 & 0.01 & 0.43 \\
\hline & & 2 & & 16063.86 & 0.992 & 0.002 & 0.81 \\
\hline & \multirow{2}{*}{ MIP OES } & 1 & \multirow{2}{*}{$0.25-1.5$} & 672308.67 & 0.999 & 0.01 & 0.27 \\
\hline & & 2 & & 668683.26 & 0.999 & 0.003 & 0.24 \\
\hline \multirow{4}{*}{ K } & \multirow{2}{*}{ F AES } & 1 & \multirow{2}{*}{$0.25-1.5$} & 14567.46 & 0.999 & 0.003 & 0.36 \\
\hline & & 2 & & 15122.71 & 0.999 & 0.003 & 0.74 \\
\hline & \multirow{2}{*}{ MIP OES } & 1 & \multirow{2}{*}{$0.25-1.5$} & 138374.93 & 0.999 & 0.002 & 0.08 \\
\hline & & 2 & & 115606.64 & 0.998 & 0.003 & 0.29 \\
\hline \multirow{4}{*}{$\mathrm{Ca}$} & \multirow{2}{*}{ F AAS } & 1 & \multirow{2}{*}{$1.0-4.0$} & 0.06 & 0.991 & 0.02 & 2.69 \\
\hline & & 2 & & 0.06 & 0.999 & 0.03 & 33.07 \\
\hline & \multirow{2}{*}{ MIP OES } & 1 & \multirow{2}{*}{$1.0-4.0$} & 532036.32 & 0.998 & 0.01 & 0.23 \\
\hline & & 2 & & 552129.78 & 0.999 & 0.01 & 0.27 \\
\hline \multirow{4}{*}{$\mathrm{Mg}$} & \multirow{2}{*}{ F AAS } & 1 & \multirow{2}{*}{$0.1-0.4$} & 0.97 & 0.999 & 0.003 & 0.18 \\
\hline & & 2 & & 0.90 & 0.999 & 0.003 & 0.83 \\
\hline & \multirow{2}{*}{ MIP OES } & 1 & \multirow{2}{*}{$0.1-0.4$} & 380869.89 & 0.997 & 0.001 & 0.03 \\
\hline & & 2 & & 353678.66 & 0.998 & 0.003 & 0.06 \\
\hline
\end{tabular}

a: slope; R: linear correlation coefficient; *equipment limit of detection; **method limit of detection.

The results obtained by FAAS/AES with the optimized conditions for the two proposed procedures, applied in the samples 2, 3, 4, 5 and 6 , are presented in the Table 7 . By applying the Tukey test, we found no significant difference at $95 \%$ confidence level between the various procedures proposed for its technical analysis. The average RSDs (\%) obtained were $4.9 \%$ for $\mathrm{Na}, 3.0 \%$ to $\mathrm{K}, 2.7 \%$ for $\mathrm{Ca}$ and $2.7 \%$ to $\mathrm{Mg}$, showing good repeatability of the proposed methods for the determination of analytes in different types of Brazilian cream cheese samples.

The samples were also analyzed by MIP OES and the concentrations obtained for the elements under study are presented in Table 7. The concentrations of the elements for the two procedures in the different analytical techniques were compared by applying the Tukey test. At $99 \%$ confidence level there was no significant difference between the procedures, showing that the results were satisfactory.

For comparison of the samples (Table 7) it was performed Tukey test at $95 \%$ level of significance. When the concentrations of $\mathrm{Na}$ between traditional Brazilian cream cheese brand A and B (samples 2 and 4) and light Brazilian cream cheese brand A and B (samples 3 and 5) were compared, no significant difference were founded. For $\mathrm{K}$ evaluation a significant difference were founded. This can occur because in some light products the $\mathrm{NaCl}$ are replaced by $\mathrm{KCl}$, resulting in an increase in the $\mathrm{K}$ concentration.

When $\mathrm{Na}$ concentrations were compared between traditional Brazilian cream cheese brand B (sample 4) and light Brazilian cream

Table 7. Concentration of $\mathrm{Na}, \mathrm{K}, \mathrm{Ca}$ and $\mathrm{Mg}\left(\mathrm{mg} \mathrm{g}^{-1}\right)$ in Brazilian cream cheese samples obtained by F AAS/AES and MIP OES after procedures 1 and 2

\begin{tabular}{|c|c|c|c|c|c|c|c|}
\hline \multirow{2}{*}{ Analyte } & \multirow{2}{*}{$\begin{array}{l}\text { Analytical } \\
\text { technique }\end{array}$} & \multirow{2}{*}{ Procedure } & \multicolumn{5}{|c|}{ Samples } \\
\hline & & & Sample 2 & Sample 3 & Sample 4 & Sample 5 & Sample 6 \\
\hline \multirow{4}{*}{$\mathrm{Na}$} & \multirow{2}{*}{ F AES } & 1 & $6.30 \pm 0.34$ & $6.97 \pm 0.58$ & $5.82 \pm 0.46$ & $7.77 \pm 0.11$ & $6.76 \pm 0.26$ \\
\hline & & 2 & $6.85 \pm 0.16$ & $7.23 \pm 0.04$ & $6.20 \pm 0.06$ & $7.82 \pm 0.15$ & $6.81 \pm 0.04$ \\
\hline & \multirow{2}{*}{ MIP OES } & 1 & $5.28 \pm 0.07$ & $5.84 \pm 0.02$ & $4.98 \pm 0.09$ & $5.51 \pm 0.05$ & $5.13 \pm 0.04$ \\
\hline & & 2 & $6.42 \pm 0.13$ & $7.07 \pm 0.09$ & $5.30 \pm 0.02$ & $6.07 \pm 0.06$ & $5.22 \pm 0.01$ \\
\hline \multirow{4}{*}{ K } & \multirow{2}{*}{ F AES } & 1 & $0.84 \pm 0.01$ & $0.31 \pm 0.01$ & $0.858 \pm 0.001$ & $1.07 \pm 0.04$ & $4.61 \pm 0.07$ \\
\hline & & 2 & $0.83 \pm 0.01$ & $0.289 \pm 0.002$ & $0.85 \pm 0.01$ & $1.096 \pm 0.004$ & $4.48 \pm 0.03$ \\
\hline & \multirow{2}{*}{ MIP OES } & 1 & $0.65 \pm 0.02$ & $0.30 \pm 0.01$ & $0.86 \pm 0.02$ & $1.02 \pm 0.01$ & $4.50 \pm 0.1$ \\
\hline & & 2 & $0.84 \pm 0.01$ & $0.35 \pm 0.02$ & $0.89 \pm 0.02$ & $1.08 \pm 0.03$ & $4.48 \pm 0.04$ \\
\hline \multirow{4}{*}{$\mathrm{Ca}$} & \multirow{2}{*}{ FAAS } & 1 & $2.15 \pm 0.01$ & $3.39 \pm 0.10$ & $3.23 \pm 0.09$ & $3.69 \pm 0.03$ & $3.26 \pm 0.02$ \\
\hline & & 2 & $2.129 \pm 0.004$ & $3.03 \pm 0.12$ & $3.13 \pm 0.01$ & $3.61 \pm 0.03$ & $3.24 \pm 0.02$ \\
\hline & \multirow{2}{*}{ MIP OES } & 1 & $2.16 \pm 0.02$ & $2.87 \pm 0.03$ & $3.07 \pm 0.14$ & $3.71 \pm 0.09$ & $3.71 \pm 0.09$ \\
\hline & & 2 & $2.10 \pm 0.1$ & $3.15 \pm 0.02$ & $3.27 \pm 0.05$ & $3.58 \pm 0.06$ & $3.58 \pm 0.06$ \\
\hline \multirow{4}{*}{$\mathrm{Mg}$} & \multirow{2}{*}{ F AAS } & 1 & $0.10 \pm 0.01$ & $0.101 \pm 0.002$ & $0.167 \pm 0.002$ & $0.226 \pm 0.002$ & $0.228 \pm 0.004$ \\
\hline & & 2 & $0.107 \pm 0.001$ & $0.107 \pm 0.001$ & $0.17 \pm 0.01$ & $0.224 \pm 0.002$ & $0.229 \pm 0.002$ \\
\hline & \multirow{2}{*}{ MIP OES } & 1 & $0.10 \pm 0.01$ & $0.101 \pm 0.003$ & $0.16 \pm 0.01$ & $0.214 \pm 0.007$ & $0.22 \pm 0.01$ \\
\hline & & 2 & $0.105 \pm 0.001$ & $0.099 \pm 0.004$ & $0.17 \pm 0.01$ & $0.23 \pm 0.01$ & $0.22 \pm 0.01$ \\
\hline
\end{tabular}

Sample 2: traditional Brazilian cream cheese brand A; Sample 3: traditional Brazilian cream cheese brand B; Sample 4: light Brazilian cream cheese (reduced fat amount) brand A; Sample 5: light Brazilian cream cheese (reduced fat amount) brand B; Sample 6: light Brazilian cream cheese (reduced fat and sodium amount) brand B. 
cheese with reduced Na brand B (sample 6), there was no significant difference. This result were not expected since in the product label of sample 6 it was informed that it is a light product with reduced $\mathrm{Na}$ amount. According to ANVISA (2012), ${ }^{28}$ for reduced sodium amount in a product, the same must present a minimum decrease of $25 \%$ related to the traditional product of the same brand.

The Ca concentrations in traditional brands (samples 2 and 4 ) and light brands (samples 3 and 5) were also compared, with a significant difference between samples. This could be explained by the addition of calcium paracaseinate for the production of light Brazilian cream cheese. The light products presents a high percentage of moisture (49\%), and the calcium paracaseinate is required to help achieve the necessary consistency to the final product.

Evaluation of $\mathrm{Mg}$ concentrations by Tukey test present no difference between traditional brands (samples 2 and 4) and light brands (samples 3 and 5).

Because of the concern about the risk of cardiovascular disease due to the increasing in the intake of $\mathrm{Na}$, daily control of this element in food processing is required. The Na present on the label of the products analyzed is informed, $5.33 \mathrm{mg} \mathrm{g}^{-1}$ for Sample $2,5.83 \mathrm{mg}$ $\mathrm{g}^{-1}$ for Sample 3, $6.10 \mathrm{mg} \mathrm{g}^{-1}$ for Sample 4, $6.63 \mathrm{mg} \mathrm{g}^{-1}$ for Sample 5 and $4.00 \mathrm{mg} \mathrm{g}^{-1}$ for Sample 6. It can be observed that, regardless of the procedure used, the values obtained (Table 7) in general are not consistent with the amounts stated on the labels, which proves the importance of controlling the amounts of this element added by the industries participants of the agreement signed with Brazil's Ministry of Health. In addition, we see the importance in the determination and quantification of essential minerals such as $\mathrm{K}, \mathrm{Ca}$ and $\mathrm{Mg}$ in dairy products, since these products are consumed as a source of nutrients.

\section{CONCLUSION}

The use of experimental design evaluates efficiently the significant variables in the preparation stage of samples and subsequent determination of elements. The acid decomposition with a reflux system and the alkaline solubilization with TMAH were efficient in the preparation of Brazilian cream cheese samples allowing the determination of the control analyte, $\mathrm{Na}$, as well as essential elements, $\mathrm{K}, \mathrm{Ca}$ and $\mathrm{Mg}$ present in Brazilian cream cheese, by F AAS (Ca, Mg) F AES ( Na, K) and MIP OES ( $\mathrm{Na}, \mathrm{K}, \mathrm{Ca}$ and $\mathrm{Mg}$ ). The main advantages of the proposed procedure when compared with the reference method were the use of small amounts of sample, less sample manipulation, which decreased significantly the number of the steps involved, minimizing possible contamination and losses during execution, as well as providing greater simplicity in the analysis, essential characteristics for routine analysis.

Thus, this study evaluates the use of two simple and efficient procedures for the preparation of Brazilian cream cheese samples, which proved to be accurate and precise for the proposed goal, showing to be viable alternatives for $\mathrm{Na}$ control and for determining the elements $\mathrm{K}, \mathrm{Ca}$ and $\mathrm{Mg}$, mostly present in Brazilian cream cheese samples, as well as versatile, since there were significant responses when using the new analytical technique, MIP OES, which is of great interest in analytical determinations for its scope of elements to be determined, the high sensitivity and for allowing multielement determinations with accurate and precise results.

\section{ACKNOWLEDGMENT}

The authors gratefully acknowledge the Conselho Nacional de Desenvolvimento Científico e Tecnológico (CNPq), Coordenação de
Aperfeiçoamento de Pessoal de Nível Superior (CAPES) and CNPq/ CAPES (Projeto Casadinho no. 552197/2011-4) for their financial support and scholarships.

\section{REFERENCES}

1. IBGE (Instituto Brasileiro de Geografia e Estatística). Pesquisa de Orçamentos Familiares (POF) 2008-2009 - Análise do Consumo Alimentar Pessoal no Brasil. Rio de Janeiro, 2011.

2. Nakasato, M.; Revista Brasileira de Hipertensão 2004, 11, 95.

3. http://www.estadao.com.br/noticias/impresso, governo-e-industria-dealimentos-fecham-acordo-para-reduzirsodio,703297,0.htm, accessed April 2017

4. Matusiewicz, H., Golik, B.; Microchem. J. 2004, 76, 23.

5. Brown, P. G.; Haas, D. L.; Workman, J. M.; Caruso, J. A.; Fricke, F. L.; Anal. Chem. 1987, 59, 1433.

6. Murillo, M.; Carrión, N.; Chirinos, J.; Gammiero, A.; Fassano, E.; Talanta 2001, 54, 389

7. Arai, Y.; Sato, S.; Wagatsuma, K.; ISIJ Int. 2013, 53, 1993

8. Karlsson, S.; Sjöberg, V.; Ogar, A.; Talanta 2015, 135, 124.

9. Ozbek, N.; Akman, S.; Food Chem. 2016, 200, 245.

10. Silva, F. V.; Lopes, G. S.; Nobrega, J. A.; Souza, G. B.; Nogueira, A. R. A.; Spectrochim. Acta, Part B 2001, 56, 1909.

11. Association of Official Analytical Chemists; Official methods of analysis of official analytical chemists, Washington, D. C., chap. 50, p. 13, 1995

12. Instituto Adolfo Lutz do Brasil; Métodos físico-químicos para análise de alimentos, $4^{\text {th }}$ ed., São Paulo, 2008.

13. Krug, F. J.; Métodos de Preparo de Amostras: Fundamentos sobre preparo de amostras orgânicas e inorgânicas para análise elementar, $1^{\mathrm{st}}$ ed., Piracicaba, 2010.

14. Ferreira, S.; Silva, L. O.; De Santana, F. A.; Junior, M. M.; Matos, G. D.; Dos Santos, W. N.; Microchem. J. 2013, 106, 307.

15. Oreste, E. Q.; Jesus, A.; Oliveira, R. M.; Silva, M. M.; Vieira, M. A.; Ribeiro, A. S.; Microchem. J. 2013, 109, 5.

16. Souza, A. O.; Pereira, C. C.; Jado, B. M.; Oreste, E. Q.; Vieira, M. A.; Ribeiro, A. S.; Vendruscolo, C. T.; Nunes, A. M.; Quim. Nova 2015, 38, 209.

17. Oreste, E. Q.; Souza, A. O.; Pereira, C. C.; Lisboa, M. T.; Cidade, M. J. A.; Vieira, M. A.; Ribeiro, A. S.; Food Analytical Methods 2015, 9, 777.

18. Oliveira, R. M., Antunes, A. C. N., Vieira, M. A., Medina, A. L., Ribeiro, A. S. Microchem. J. 2016, 124, 402.

19. Nóbrega, J. A.; Santos, M. C.; Sousa, R. A.; Cadore, S.; Barnes, R. M.; Tatro, M.; Spectrochim. Acta, Part B 2006, 61, 465.

20. Ribeiro, A. S.; Moretto, A. L.; Arruda, M. A. Z; Cadore, S.; Microchim. Acta 2003, 141, 149.

21. Nóbrega, J. A.; Gélinas, Y.; Krushevska, A.; Barnes, R. M.; J. Anal. At. Spectrom. 1997, 12, 1243

22. Würfles, M.; Jackwerth, H.; Stoeppler, M.; Fresenius' Z. Anal. Chem. 1988, 330, 160 .

23. Spellmeier, J. G.; Dissertação de mestrado. Universidade Federal de Santa Maria, Brazil, 2011.

24. Damodaran, S.; Parkin, K. L.; Fennema, O. R.; Química de alimentos de Fennema, Artmed: Porto Alegre, 2010.

25. De La Fuente, M. A.; Juárez, M.; Analyst 1995, 120, 107.

26. Momen, A. A., Zachariadis, G. A., Anthemidis, A. N., Stratis, J. A.; Talanta 2007, 71, 443.

27. http://www.fda.gov/downloads/drugs/guidancecomplianceregulatoryin formation/guidances/ucm386366.pdf, accessed April 2017.

28. http://bvsms.saude.gov.br/bvs/saudelegis/anvisa/2012/ rdc0054_12_11_2012.html, accessed April 2017. 